This item was submitted to Loughborough's Research Repository by the author.

Items in Figshare are protected by copyright, with all rights reserved, unless otherwise indicated.

\title{
Book review: The social construction of rationality: policy debates and the power of good reasons
}

\section{PLEASE CITE THE PUBLISHED VERSION}

https://doi.org/10.1177/1350508418768056

\section{PUBLISHER}

(C) The authors. Published by SAGE Publications Ltd

\section{VERSION}

AM (Accepted Manuscript)

\section{PUBLISHER STATEMENT}

This work is made available according to the conditions of the Creative Commons Attribution-NonCommercialNoDerivatives 4.0 International (CC BY-NC-ND 4.0) licence. Full details of this licence are available at: https://creativecommons.org/licenses/by-nc-nd/4.0/

\section{LICENCE}

CC BY-NC-ND 4.0

\section{REPOSITORY RECORD}

Dolfsma, Wilfred. 2019. "Book Review: The Social Construction of Rationality: Policy Debates and the Power of Good Reasons". figshare. https://hdl.handle.net/2134/28118. 
Onno Bouwmeester (2017) The Social Construction of Rationality - Policy Debates and the Power of Good Reasons. London \& New York: Routledge (isbn 978-1-138-85108-5 [hbk, f105]; isbn 978-1-31572437-9 [ebk, f24.49]); pp. xii, 203.

Bouwmeester employs a conveniently broad and common-sense definition of rationality in this thought-provoking book: decisions are rational when one has good reasons for making them. In an era where behaviouralism flourishes and has even reached the vestiges of mainstream economic thought, reconsideration of what rationality actually is, is well-timed. I would implore all readers whose minds and work is focused on decision making by individuals in isolation or in groups to consult this academic work. I do so not because enough definitive answers can be gleaned from this work, but because it revisits a key theme for the social sciences and provokes thought.

The book reviews the literature on the concept of rationality and introduces three kinds of rationality: instrumental (economic) (IR), social (SR), and expressive (ER). The book also offers insights into how one is to understand which of the rationalities that has been played out and when. To further flesh out and explain these rationalities, Bouwmeester presents six different cases focusing on policy debates in two countries (UK and Netherlands). These offer insights into how ratinalitiesrationalities works out in real life.

At times, the review of the different rationality concepts around in the literature is confusing. In particular, reference to 'domains of', 'perspectives for' and 'degrees of' rationality are unclear. Suggesting that bounded rationality is a different kind of rationality (e.g., p. 44), rather than, as Herbert Simon (1961: xxiv) claimed, "intendedly [instrumentally] rational but only limitedly so", is more than just a little confusing. Different kinds of rationality pass by in the book, beyond the three the author settles for. It is thus not clear why the three proposed kinds of rationality are the best.

Bouwmeester is keen to be able to indicate when a decision is rational and when it is irrational. When 'unintended effects' from actions and decisions materialize the reasons for these actions and decisions are then deemed to be irrational by definition. Yet, in a complex and uncertain world (perhaps 'Knightian' uncertainty - see Knight 1964), time frame and availability of information come into play. When additional information becomes available (much) later that would have led one to make a different decision, does an initial decision taken in the past become irrational ex post? Bouwmeester seems to claim it does.

The chapter on method is very useful, but, alas, not obviously and ostentatiously followed by Bouwmeester himself in the empirical chapters that ensue. More about the choice for the cases, the data to be analysed, and the correct interpretation of the data using appropriate coding schemes could be included in the book. The good thing about writing a book is that the usual space limit for an article is less binding. Still, the analysis makes a lot of sense for someone who is famililarfamiliar with both societies from which the cases are drawn. More detailed references to empirical material, including to articles in a newspaper such as Rotterdams Dagblad, to which my parents used to be subscribed, would not go lost on me. To the contrary, even if presented in endnotes, they would have persuaded me in regards to the thoroughness of the research.

Further explanations would, for instance, make it clear why Bouwmeester would contend that 'many muslims' are upset by a possible veil ban for expressive rationality reasons rather than social rationality reasons (p.165). How many people are needed for reasons provided to turn into good reasons from a social rationality point of view? Do the kinds of arguments used make them rational according to some type? Or does it perhaps, and more darkly, matter which group of individuals expresses the reasons? The suggestion that some social values are more important, because "more universal and more fundamental" (p.144) raises more questions than it answers.

Bouwmeester provides a very useful template to analyse a debate / decision, even though it is unclear what the source of the template is. Even so, I will certainly be using it in my own thinking as 
an academic administrator. The template is proven to be very useful in all of the 6 cases discussed in the 3 empirical chapters. While practically valuable, the template used to analyse discussions oddly decontextualizes the debates - the 'social construction' of rationality from this book's title is not clearly explained in the book, and seems a mere reference to the acclaimed Berger \& Luckman social construction of reality (1966) book.

Bouwmeester's penultimate chapter, on rationalities' interplay, is a bit of a let-down as the cases are not really used to spell out how rationality interplays might work. The rationality concepts could be more central in this important chapter, rather than focusing on the cases. This might have provided arguments spelling out the conceptual model presented: how does, for instance, 'motivational and inductively linked arguments' allow expressive rationality (ER) to persuade ('check') instrumental rationality (IR)? Conceptually, the interplay between rationalities is depicted in a useful model on p.159. Even so, this reviewer would have liked to see a clearer conceptual link from that model to the irrationality checks with which the book concludes (Table 7.3, pp.185-6). The ' $E R \rightarrow I R$ irrationality check' is this question: "are arguments suggesting means to realize ends sufficiently aligned with what decision makers and relevant stakeholders desire, or care about?" The check would be a handy tool for policy makers, managers of organizations and consultants, but could use some more conceptual development to be useful for organization scholars.

The concept of rationality is or should be at the core of conceptualizing in the social sciences. The critique levelled against this book might seem heavy-handed, but Bouwmeester's project is a profoundly important one and I congratulate him for the contributions he makes. In recent decades, the concept of rationality has either been ignored, assumed to be thoroughly understood, or discussed in separate corners in academia. Bouwmeester brings recent insights together, adds new insights that are conceptually relevant and actionable in the realities of public policy and organization, and also shows there is more work to be done. Bouwmeester's project is not done yet, and I hope for important new contributions from him in the future!

References:

Berger, P.L. and Th. Luckmann (1966) The Social Construction of Reality. London: Penguin.

Knight, F.H. (1964) Risk, Uncertainty and Profit. New York: Kelley.

Simon, H.A. (1961) Administrative Behavior, $2^{\text {nd }}$ Edition. New York: Macmillan. 